\title{
Risk or Resilience? What Makes a Difference?
}

\author{
Helen J Boon \\ James Cook University
}

\begin{abstract}
Dropping out of school has been associated with a student's ethnicity, socioeconomic status, challenging behaviours and low academic achievement. This paper describes research conducted with 1050 students aged 12-15, in three North Queensland urban high schools to investigate issues related to Indigenous and non-Indigenous students at risk of dropping out of school before gaining adequate qualifications.

A path-analytic model was developed to assess the influence of socio-demographic, structural family and behavioural factors upon low academic achievement, the strongest predictor of dropping out of school. The specific bypothesis tested was that challenging behaviour, indexed by suspensions, predicts low academic achievement or at-risk status, more strongly than SES or family structure variables.

Results indicate that for both Indigenous and non-Indigenous students, suspensions are a stronger predictor of low achievement than socioeconomic or family factors. Moreover, a model testing low achievement as a precursor to suspensions was not supported. Suggestions for future practice and research are proposed.
\end{abstract}

\section{Introduction}

Headlines in Brisbane's Courier-Mail on November $17^{\text {th }} 2003$ (Odgers, 2003) reported that 30 students are permanently excluded from Queensland government schools every week. This approximates to 1200 exclusions per year. Exclusions are strong indicators of a student at risk of dropping out of school (Batten \& Russell, 1995). This paper reports results from an investigation into some of the factors associated with dropping out of school in two secondary school populations, Indigenous and nonIndigenous students.

Students who drop out of school before completing their secondary education have been a cause for ongoing concern among educators, parents and the community at 
large for a considerable time. Students might fail to complete their secondary education because they are disaffected with school. This disaffection has a number of manifestations including, absenteeism, disruptive classroom behaviour, and exclusions or suspensions from school. Students who leave school early have been shown to have an overall poorer quality of life, evidenced by a range of marginalised employment opportunities (McMillan \& Marks, 2003), delinquent activities (Lane, 1999; Hinshaw, 1992; Rutter, Giller, \& Hagell, 1998), and psychological, social and financial adjustment issues (Chamberlain \& MacKenzie, 1996). A student perceived to be disaffected is said to be at-risk (Batten \& Russell, 1995).

The urgency of the issue is reflected in the number of students at risk of dropping out. This number is estimated by looking at apparent retention rates. These rates report the total number of students who stay on at school from Year 8 through to Year 12. Students at-risk, those who did not complete Year 12, are then estimated from these figures. Rothman (2004) summarized Australian retention trends:

In 1967, the apparent retention rate in Australian schools was 22.7 percent. Over the next eight years, this rate grew to 34.1 percent, and then remained close to that point until 1982, when it began to increase again. Over the following ten years, the rate more than doubled, growing from 36.3 percent in 1982 to 77.1 percent in 1992. The rate peaked in 1992, and has remained above 72 percent into the 2000s. In 2002, the Year 7-12 apparent retention rate was 75.1 percent. (p. 113)

The overall retention rate in Australia was 75.7 percent in 2004, while for Indigenous students it was only 39.5 percent, an increase from the 1993 Indigenous retention level of 25 percent (ABS, 2004). Although these rates show improvement, in a context where the compulsory phase of schooling in Australia determines that from 2006 an adolescent must complete Year 10, or remain in school until the age of 16, they are not good enough (Hill, Dawes, Boon \& Hillman, 2005). We need to find ways to transform risk to resilience. To do that we need to know what renders students atrisk, and what characterises resilience.

Neither of these questions is new. In 2000, Jimerson, Egeland, Sroufe and Carlson stated:

Five decades of research have uncovered numerous correlates of withdrawal from high school. Prior research highlights various demographic status variables, individual characteristics, psychological and behavioural measures, and family factors associated with high school drop out. They are now well known but not always useful. (p. 526) 
Reference to youth and children at-risk first came into wide use in the 1980s. Originally this referred to dangerous environments, such as disrupted families and dysfunctional schools. But terms like at-risk adolescents and high risk behaviour shifted the focus from how to build supportive environments to finding supposed defects in the adolescent. Those who labelled youth as "violent" or "predators" created a fear of dangerous adolescents while letting adults off the hook (Males, 1996). Thomson (2002) contends that analyses of "risk" are chosen from models structured around individual student cases or "the social, cultural, economic, political and institutional processes and practices in which these young people are collectively positioned" (p. 64). Thomson (2002) further contends that by focusing on individual student attributes policymakers and researchers omit to account for the socio-cultural and political conditions, often spanning several generations, responsible for constructing the at-risk trajectory.

Views reflecting Thomson's (2002) perspective have a long history. Radical sociologists like Willis (1979) for example, similarly argued that working-class, black and female students were denied equality of educational opportunity and that community and family deficits were not the causes of being at-risk. Twenty years later structural inequality still pervades students' academic outcomes, as demonstrated by international empirical findings that consistently show a positive correlation between measures of socio-economic status (SES) and school achievement (e.g., OECD, 2001).

However, not all socially disadvantaged students are at-risk and, conversely, not all advantaged students are academically successful. Although social inequalities are likely to be a persistent source of frustration for educators, parents, sociologists and even some politicians, psychologists espouse a more optimistic, proactive view: a view that offers the opportunity for timely local support at the individual level, while the remote wheels of social, educational and curricular reform grind very slowly onwards. For as Teese (2001) revealed in his detailed review of curricular 'reform and counter reform': "even major changes in systems of subjects, thorough revision of content and varied assessment methodologies produce little discernible impact on social patterns of (academic) results" (p. 194).

\section{Low academic achievement, resilience, challenging behaviour and dropping out of school}

Several important factors that lead to dropping out of school have been identified. Of these, low academic achievement has been consistently found to strongly predict dropping out of school (e.g. Battin-Pearson, Newcomb, Abbott, Hill, Catalano, \& Hawkins, 2000; Bradley, 1992). McMillan and Marks (2003), reporting on student 
dropouts in Australia, concluded: "Not only are low achievers more likely to leave school early, they are among the first to do so" (p. 86).

It might be tempting to believe that low academic achievement is due to low ability levels. Conceding that cognitive ability, as measured by IQ scores, has a strong relationship with measures of achievement (e.g. Yen, Konold, \& McDermott, 2004; Reynolds, Lowe \& Saenz, 1999), empirical evidence has demonstrated learning behaviour, marked by attentiveness, persistence and engagement with a learning task, adds substantially to the prediction of higher academic achievement (e.g. Yen, Konold, \& McDermott, 2004). Research conducted in Australia in a school for students at-risk characterised by low academic achievement showed that 57 percent of students had average IQs while 30 percent had above average IQs (Candy \& Baker, 1992). Similarly, researchers from the United Kingdom concluded that students in pupil referral units lacked suitable motivational and coping strategies to support their learning, not cognitive ability (Solomon \& Rogers, 2001). Moreover, meta-analysis of several research studies has led American researchers to deduce that IQ accounts for only 25 per cent of the variance in schooling outcomes (Sternberg, Grigorenko, \& Bundy, 2001). Therefore, (low) academic achievement, the most important factor in predicting dropping out of school, is strongly linked to motivational behaviours. These behaviours are fostered in the environments in which students participate. These environments, home, school, communities, can enhance behaviours that lead to either an at-risk trajectory or academic resilience. An urgent task for educators, counsellors, and social workers is to understand the issues surrounding students atrisk due to low achievement in order to support them in the path to resilience.

Resilience is characterised by academic success where socio-economic and structural family factors would predict failure (Gordon Rouse, 2001). More recently, Schoon (2006) defined resilience as academic attainment in the face of socioeconomic adversity. Socioeconomic adversity is a major risk factor acknowledged to influence childrens' and adolescents' social and emotional functioning, as well as their cognitive competence. For Schoon (2006) socioeconomic adversity is represented by "living conditions, characterised by low social status, poor housing, overcrowding, and lack of material resources" (p. 9).

Studies of adolescent resilience highlight a number of personal, biological and psychological factors. Resilient adolescents are more socially responsible, friendly, with excellent social skills, (Garmezy \& Rutter, 1983; Werner, 1993), independent, and cognitively and academically superior to their counterparts (Werner, 1990). In other words, they are well adjusted to and able to meet the demands of school and society. It is this adjustment to school that is of concern to this study. Resilient students also have support from a parent or significant other to assist them to meet challenging 
situations. Lack of such support has been claimed to place young Australians at risk of failure (Withers \& Batten, 1995).

One indicator of adjustment to school is challenging behaviour leading to and measured by suspensions (Jimerson et al., 2000). Challenging behaviour, often exhibited by students at-risk, is broadly divided into two: externalizing, where problems are directed towards others and the environment, and internalizing, where problems turn inwards towards the self. Externalizing behaviours typically involve an acting-out style of responding that includes a repertoire of behaviours such as aggression, arguing, impulsivity and disobedience. On the other hand, internalizing behaviours withdraw the student from participation and may lead to absenteeism. These students often experience emotional difficulties such as anxiety, phobias, fearfulness, depression, loneliness and somatic symptoms like headaches and stomach-aches (Gresham, Lane, MacMillan, \& Bocian, 1999). Internalizing and externalizing behaviours result in frequent referrals and suspensions. McEvoy and Welker (2000) contend that academic failure and challenging behaviours exist in a reciprocal relationship, exacerbated within the context of ineffective school practices.

\section{Developmental perspectives surrounding risk and resilience issues}

Factors cited as instrumental to an at-risk trajectory such as low academic achievement and externalising behaviours do not necessarily act independently but may reinforce each other or set up conditions that predispose risk or resilience. For example, after a low test result, an adolescent may increase their effort to improve scores or may withdraw from academic work, depending upon the influence of particular family or school contexts, the interaction between them, or the interaction between the adolescent and either or both contexts. Academic withdrawal, or disengagement, might lead to behaviours that predispose suspensions. Developmental psychologists view risk as resulting from the reciprocal interchanges between a child/adolescent and their social network of family, school, peers, and community (Bronfenbrenner, 1986). The contexts where students participate, including school and home, contain many social interactions that contribute to identity formation. It is here, at the micro level, that academic resilience can be fostered.

Empirical work suggests that parenting is highly instrumental in promoting healthy adjustment or behaviour problems in children. Furthermore, Christenson, Hurley, Sheridan and Fenstermacher (1997) assert that variables related to parental attitudes and behaviour are more important than SES in predicting academic achievement. For example, Kelley, Brownell, and Campbell (2000) demonstrated that maternal positive 
feedback predicted the child's later persistence in tackling academic tasks, and maternal guidance resulted in less avoidance of challenging tasks a year later. Parental behaviour, and in turn academic success, appears to be linked to family structure. An extensive literature review conducted in Great Britain to assess the impact of parental involvement on achievement supports the notion that parenting processes, which are linked to maternal education, SES, and family structure, mediate student achievement even when all the other factors shaping attainment are controlled (Desforges \& Abouchaar, 2003). The authors conclude that parenting influences academic achievement indirectly by shaping the child's self-concept as a learner and through communicating high aspirations for the child. A lack of suitable parenting may result in externalising or internalising problems, leading ultimately to suspensions and dropping out of school (Lamborn, Mounts, Steinberg, \& Dornbusch,1991).

In sum, not only do structural family factors and behaviours influence risk and resilience in adolescents, but also the cultural context of those interchanges is likely to be highly implicated in shaping those interactions. It is for this reason that substantial differences might be apparent between Indigenous and non-Indigenous students' interactions with, and adjustment to, the school environment leading to academic resilience or an at-risk trajectory.

\section{Study Aims}

The current study aims to validate previous work conducted with students at-risk in the United States (Jimerson et al., 2000) and in Australia (Candy \& Baker, 1992). This work suggests the most proximal predictor of dropping out of school is challenging behaviour because it is highly linked to low achievement, the strongest predictor for dropping out (Battin-Pearson, Newcomb, Abbott, Hill, Catalano, \& Hawkins, 2000; Bradley, 1992). In this study, challenging behaviour is indexed by suspensions. The hypothesis tested is that challenging behaviour, indexed by suspensions, predicts low academic achievement or at-risk status, more strongly than SES and family structure variables.

Because behaviour is a product of current circumstances and prior developmental history (Rutter, 2002; Jimerson et al., 2000) students in Years 8 to 10 are included in order to test the hypothesis that there is a greater tendency to become at-risk, and therefore drop out, in the later years of high school. In addition, because of the widening gaps between Indigenous students' literacy and numeracy compared to other Australian students (Miller \& Spooner, 2004), the analyses are applied separately to the two samples of students, Indigenous and non-Indigenous, in order to compare and contrast differences and similarities between the two groups. Reviewing contemporary Indigenous research in Australia, Mellor and Corrigan (2004) have 
argued there is a dearth of empirical quantitative research within the Indigenous education literature. They note that the research methodology employed in current studies is limited by its focus on small case studies derived from communities with a high Indigenous population, thus isolating Indigenous education research from the broader discourses of disciplines such as psychology, sociology and health.

\section{Methods}

\section{Participants}

The sample consisted of 1127 Year 8-10 students, aged 12-15, from three state high schools in a regional city in North Queensland, Australia. In order to maximise student participation, parents were sent letters informing them of the study and requesting that parental permission forms were to be returned only if they did not wish their child to participate. The resulting sample represented $81 \%$ of the students enrolled in the schools present on the days data were collected. Self-report questionnaires were completed during a 45 minute class period between two and four weeks after midyear report cards were sent to students. 1050 complete questionnaires were obtained; the remaining 77 surveys were randomly missing either names or various parts and so were not included. The principal researcher randomly checked $15 \%$ of the student responses for accuracy with the participating schools as students supplied their names on the questionnaire.

\section{Measures}

Since academic achievement is used as the index of at-risk status, students were separated into two groups for all preliminary analyses according to their English and mathematics grades: not at-risk (grades "C" and above) and at-risk (grades below "C").

1) Academic achievement: English and mathematics mid-year grades are recorded as grades following the approach used by Paulson, Marchant and Rothlisberg (1998). The grades are coded Very limited (E), Limited (D), Sound (C), High (B) and Very high (A) (reverse coded for use in the structural equation modelling analyses). Achievement scores of D-E for English and mathematics are used to construct the category of students at-risk. These students comprise $19.8 \%$ of the sample used in this study.

2) Suspensions (challenging behaviour): Students reported the number of times they were suspended. These were coded: never suspended (0), suspended (1).

3) Socioeconomic and family structure variables: Paternal and maternal employment were recorded as (0) for unemployed and (1) for employed. Paternal and maternal education was coded as (0) for 
education only up to high school and (1) for graduate level and above for each parent following the approach used by Richters and Martinez (1993).

4) Family structure: Living arrangements: if living with both biological parents, (1) any other blended family combination (0) following Astone and McLanahan's (1991) approach.

5) Year level: Year 8 coded (0); Years $9 / 10$ coded (1). This grouping was formed to enable structural equation modelling of three possible categories. The variable was included because chi-square tests showed non-Indigenous students in Years 9/10 were significantly more likely to be at-risk than those in Year 8 (Table 3). The percentage of Indigenous students being at-risk also increased with each successive year at school, though, perhaps due to the smaller sample size, results of chi-square tests of association were not significant (Table 4).

\section{Results}

The SPSS program was used to perform all statistical analyses while the structural equation path models (SEM) were developed using the AMOS 6.0 program (Arbuckle \& Wothke, 1999). Tables 1 and 2 show the distribution of achievement grades for both samples and the distribution of suspensions associated with each achievement grade. Tables 3 and 4 provide a summary of participant characteristics. Chi-squared association tests were performed to assess the strength of relationship between structural or behavioural factors and academic achievement. The results of these tests are shown in Tables 3 and 4 ( $\chi^{2 /}$, Fisher's exact statistic). As gender was not found to be significantly linked with academic failure in either group it was not investigated further.

Notable differences between the two groups include the observation that Year 9 and 10 non-Indigenous students had higher levels of failure than Year 8 students, perhaps showing a developmental trend. Higher paternal education did not reach significance in Indigenous students. This was not the case for non-Indigenous students for whom lower paternal education was linked to being at-risk. Suspensions and family structure were most highly linked to academic failure for both groups, with intact biological family structure being a protective factor against academic failure. The next step in the analysis was to fit these variables into an SEM model to account for the relationship between socioeconomic variables, suspensions, year level and being at academic risk. 


\begin{tabular}{l|c|c|c|c|c}
\hline \multirow{2}{*}{\multicolumn{2}{c|}{ Grades }} & \multicolumn{2}{c|}{ Indigenous } & \multicolumn{2}{c}{ Non-Indigenous } \\
\cline { 3 - 6 } \multicolumn{2}{l|}{} & N & $\%$ & N & $\%$ \\
\hline English & D & 17 & 16.5 & 88 & 9.3 \\
\hline & C & 44 & 42.7 & 389 & 41.1 \\
\hline & B & 25 & 24.3 & 318 & 33.6 \\
\hline & A & 9 & 8.7 & 125 & 13.2 \\
\hline \multirow{2}{*}{$\begin{array}{l}\text { Total (N) } \\
\text { Mathematics }\end{array}$} & E & 12 & 11.7 & 39 & 4.1 \\
\hline & D & 25 & 24.3 & 135 & 14.3 \\
\hline & C & 37 & 35.9 & 295 & 31.2 \\
\hline & B & 20 & 19.4 & 226 & 23.9 \\
\hline & A & 9 & 8.7 & 252 & 26.6 \\
\hline Total (N) & & 103 & & 947 & \\
\hline
\end{tabular}

Table 1: Academic achievement of Indigenous and non-Indigenous students

\begin{tabular}{l|c|c|c|c|c}
\hline \multicolumn{2}{c}{ Grades } & \multicolumn{2}{c|}{$\begin{array}{c}\text { Indigenous } \\
\text { Suspension }\end{array}$} & \multicolumn{2}{c}{$\begin{array}{c}\text { Non-Indigenous } \\
\text { Suspension }\end{array}$} \\
\cline { 3 - 6 } & & $\begin{array}{c}\text { Never } \\
\%\end{array}$ & $\begin{array}{c}\text { Suspended } \\
\%\end{array}$ & $\begin{array}{c}\text { Never } \\
\%\end{array}$ & $\begin{array}{c}\text { Suspended } \\
\%\end{array}$ \\
\hline English & E & 12.5 & 87.5 & 40.7 & 59.3 \\
\hline & D & 47.1 & 52.9 & 55.7 & 44.3 \\
\hline & C & 77.3 & 22.7 & 84.8 & 15.2 \\
\hline & B & 96.0 & 4.0 & 90.3 & 9.7 \\
\hline & A & 55.6 & 44.4 & 90.4 & 9.6 \\
\hline & E & 16.7 & 83.3 & 35.9 & 64.1 \\
\hline & D & 60.0 & 40.0 & 66.7 & 33.3 \\
\hline & A & 75.7 & 24.3 & 82.0 & 18.0 \\
\hline & B & 95.0 & 5.0 & 93.8 & 6.2 \\
\hline
\end{tabular}

Table 2: Suspensions by achievement level for Indigenous and non-Indigenous students 


\begin{tabular}{|c|c|c|c|c|c|c|c|c|c|}
\hline \multirow{2}{*}{$\begin{array}{l}\text { Student } \\
\text { Characteristic }\end{array}$} & & \multicolumn{2}{|c|}{ At-risk } & \multicolumn{2}{|c|}{ Not At-risk } & \multirow[t]{2}{*}{$\chi^{2}$} & \multirow[t]{2}{*}{$d f$} & \multirow[t]{2}{*}{$p$} & \multirow[t]{2}{*}{ Variance } \\
\hline & & $N$ & $\%$ & $\mathrm{~N}$ & $\%$ & & & & \\
\hline Student Sex & $\begin{array}{l}\text { Male } \\
\text { Female }\end{array}$ & $\begin{array}{l}97 \\
84\end{array}$ & $\begin{array}{l}20.7 \\
17.5\end{array}$ & $\begin{array}{l}371 \\
395\end{array}$ & $\begin{array}{l}79.3 \\
82.5\end{array}$ & 1.55 & 1 & .212 & (NS) \\
\hline Family & $\begin{array}{l}\text { Non-intact Family } \\
\text { Biological Intact Family }\end{array}$ & $\begin{array}{l}98 \\
83\end{array}$ & $\begin{array}{l}27.8 \\
13.9\end{array}$ & $\begin{array}{l}254 \\
512\end{array}$ & $\begin{array}{l}72.2 \\
86.1\end{array}$ & 27.6 & 1 & .001 & 17.1 \\
\hline Year Level & $\begin{array}{l}\text { Year } 8 \\
\text { Year } 9 \\
\text { Year } 10\end{array}$ & $\begin{array}{l}45 \\
54 \\
82\end{array}$ & $\begin{array}{l}13.2 \\
18.9 \\
25.6\end{array}$ & $\begin{array}{l}296 \\
232 \\
238\end{array}$ & $\begin{array}{l}86.8 \\
81.1 \\
74.4\end{array}$ & 16.5 & 2 & .001 & 13.1 \\
\hline $\begin{array}{l}\text { Father's } \\
\text { Education }\end{array}$ & $\begin{array}{l}\text { Non-graduate } \\
\text { Graduate }\end{array}$ & $\begin{array}{l}161 \\
20\end{array}$ & $\begin{array}{c}22.3 \\
8.9\end{array}$ & $\begin{array}{l}561 \\
205\end{array}$ & $\begin{array}{l}77.7 \\
91.1\end{array}$ & 20.0 & 1 & .001 & 14.5 \\
\hline $\begin{array}{l}\text { Mother's } \\
\text { Education }\end{array}$ & $\begin{array}{l}\text { Non-graduate } \\
\text { Graduate }\end{array}$ & $\begin{array}{c}156 \\
25\end{array}$ & $\begin{array}{c}23.1 \\
9.2\end{array}$ & $\begin{array}{l}519 \\
247\end{array}$ & $\begin{array}{l}76.9 \\
90.8\end{array}$ & 24.3 & 1 & .001 & 16.0 \\
\hline Suspensions & $\begin{array}{l}\text { Never Suspended } \\
\text { Suspended }\end{array}$ & $\begin{array}{c}103 \\
78\end{array}$ & $\begin{array}{l}13.0 \\
49.7\end{array}$ & $\begin{array}{c}687 \\
79\end{array}$ & $\begin{array}{l}87.0 \\
50.3\end{array}$ & 113.8 & 1 & .001 & 35.0 \\
\hline Father's Work & $\begin{array}{l}\text { Unemployed/ } \\
\text { Don't Know Employed }\end{array}$ & $\begin{array}{l}39 \\
142\end{array}$ & $\begin{array}{l}29.5 \\
17.4\end{array}$ & $\begin{array}{c}93 \\
673\end{array}$ & $\begin{array}{l}70.5 \\
82.6\end{array}$ & 10.8 & 1 & .001 & 11.0 \\
\hline Mother's Work & $\begin{array}{l}\text { Unemployed/ } \\
\text { Don't Know Employed }\end{array}$ & $\begin{array}{c}65 \\
116\end{array}$ & $\begin{array}{l}28.4 \\
16.2\end{array}$ & $\begin{array}{l}164 \\
602\end{array}$ & $\begin{array}{l}71.6 \\
83.8\end{array}$ & 16.8 & 1 & .001 & 13.3 \\
\hline Total & & 181 & 19.1 & 766 & 80.9 & & & & \\
\hline
\end{tabular}

Table 3: Demographic characteristics non-Indigenous students $(\mathrm{N}=947)$

\section{Structural equation modelling (SEM) strategy}

The primary purpose of the study was to examine the structural relationships between low achievement (at-risk) and sociodemographic and behavioural predictors and to evaluate the extent to which these hold across the two ethnic groups. Structural equation modelling is also known as covariance structure modelling and simultaneous equation modelling. SEM is very useful for multi-sample modelling, wherein a model is fit simultaneously to sample data from different populations (MacCallum \& Austin, 2000). SEM also helps to overcome the problems associated with the effects of measurement error and correlated measurement error on the outcome variable (Baron \& Kenny, 1986) which attenuate the estimation of relationships between observed variables (Kline, 1998; Maruyama, 1998). Multiple predictor variables can be simultaneously modelled and their relative contribution to the outcome variable estimated, resulting in a more accurate weighting of influences for a particular outcome. This is not possible with association tests preformed for each predictor variable. Moreover, SEM techniques developed over the last two decades permit the use of dichotomous categorical predictor variables in a model without the need to employ more complicated logistic regression models (Joreskog \& Sorbom, 1984; Muthen, 1984). Where data is not continuous, as in the case with suspensions, 
SEM provides a valuable analytical tool by permitting the use of dichotomous variables. The assumption of multivariate normality need not apply to the exogenous (measured) variables (Bollen, 1989, pp. 126-28). However, lack of multivariate normality usually inflates the chi-square fit statistic such that the possibility of the model being rejected due to Type I error is increased (Kline, 1998). While causality is not confirmed by SEM techniques, since the data are not longitudinal, the model shows the relative contribution of each exogenous variable to the outcome variable, being "at-risk".

\begin{tabular}{|c|c|c|c|c|c|c|c|c|c|}
\hline \multirow{2}{*}{$\begin{array}{l}\text { Student } \\
\text { Characteristic }\end{array}$} & & \multicolumn{2}{|c|}{ At-risk } & \multicolumn{2}{|c|}{ Not At-risk } & \multirow{2}{*}{$\begin{array}{c}\chi^{2} \\
\text { Fisher's } \\
\text { Exact Test }\end{array}$} & \multirow[t]{2}{*}{$d f$} & \multirow[t]{2}{*}{$p$} & \multirow[t]{2}{*}{ Variance } \\
\hline & & $N$ & $\%$ & $\mathrm{~N}$ & $\%$ & & & & \\
\hline Student Sex & $\begin{array}{l}\text { Male } \\
\text { Female }\end{array}$ & $\begin{array}{l}15 \\
22\end{array}$ & $\begin{array}{l}37.5 \\
34.9\end{array}$ & $\begin{array}{l}25 \\
41\end{array}$ & $\begin{array}{l}62.5 \\
65.1\end{array}$ & .07 & 1 & .790 & (NS) \\
\hline Family & $\begin{array}{l}\text { Non-intact Family } \\
\text { Biological Intact Family }\end{array}$ & $\begin{array}{c}29 \\
8\end{array}$ & $\begin{array}{l}46.8 \\
19.5\end{array}$ & $\begin{array}{l}33 \\
33\end{array}$ & $\begin{array}{l}53.2 \\
80.5\end{array}$ & 7.97 & 1 & .005 & 28.0 \\
\hline Year Level & $\begin{array}{l}\text { Year } 8 \\
\text { Year } 9 \\
\text { Year } 10\end{array}$ & $\begin{array}{l}11 \\
15 \\
11\end{array}$ & $\begin{array}{l}28.9 \\
34.1 \\
52.4\end{array}$ & $\begin{array}{l}27 \\
29 \\
10\end{array}$ & $\begin{array}{l}71.1 \\
65.9 \\
47.6\end{array}$ & 3.34 & 2 & .188 & (NS) \\
\hline $\begin{array}{l}\text { Father's } \\
\text { Education }\end{array}$ & $\begin{array}{l}\text { Non-graduate } \\
\text { Graduate }\end{array}$ & $\begin{array}{c}35 \\
2\end{array}$ & $\begin{array}{l}37.6 \\
20.0\end{array}$ & $\begin{array}{c}58 \\
8\end{array}$ & $\begin{array}{l}62.4 \\
80.0\end{array}$ & $1.22^{*}$ & 1 & .324 & (NS) \\
\hline $\begin{array}{l}\text { Mother's } \\
\text { Education }\end{array}$ & $\begin{array}{l}\text { Non-graduate } \\
\text { Graduate }\end{array}$ & $\begin{array}{c}35 \\
2\end{array}$ & $\begin{array}{l}39.3 \\
14.3\end{array}$ & $\begin{array}{l}54 \\
12\end{array}$ & $\begin{array}{l}60.7 \\
85.7\end{array}$ & 3.30 & 1 & .069 & 18.0 \\
\hline Suspensions & $\begin{array}{l}\text { Never Suspended } \\
\text { Suspended }\end{array}$ & $\begin{array}{l}18 \\
19\end{array}$ & $\begin{array}{l}25.0 \\
61.3\end{array}$ & $\begin{array}{l}54 \\
12\end{array}$ & $\begin{array}{l}75.0 \\
38.7\end{array}$ & 12.4 & 1 & .001 & 35.0 \\
\hline Father's Work & $\begin{array}{l}\text { Unemployed/ } \\
\text { Don't Know Employed }\end{array}$ & $\begin{array}{l}16 \\
21\end{array}$ & $\begin{array}{l}50.0 \\
29.6\end{array}$ & $\begin{array}{l}16 \\
50\end{array}$ & $\begin{array}{l}50.0 \\
70.4\end{array}$ & 4.0 & 1 & .046 & 20.0 \\
\hline Mother's Work & $\begin{array}{l}\text { Unemployed/ } \\
\text { Don't Know Employed }\end{array}$ & $\begin{array}{l}18 \\
19\end{array}$ & $\begin{array}{l}43.9 \\
30.6\end{array}$ & $\begin{array}{l}23 \\
43\end{array}$ & $\begin{array}{l}56.1 \\
69.4\end{array}$ & 1.9 & 1 & .170 & (NS) \\
\hline Total & & 37 & 35.9 & 66 & 64.1 & & & & \\
\hline
\end{tabular}

*Fisher's exact test used as cells have expected count of less than 5.

Table 4: Demographic characteristics of Indigenous students ( $N=103)$

Various fit statistics are used to evaluate the models. Because the chi-square fit index is highly sensitive to sample size, overall model fit was also assessed by examining the Comparative Fit Index (CFI; Bentler, 1990) and the Goodness-of-Fit Index (GFI), for which values of .90 or greater are considered adequate (Byrne, 2001). Observed exogenous variables were allowed to co vary. The resulting model, Model 1, applied to the non-Indigenous students $(\mathrm{N}=947)$ is shown in Figure 1. The variance accounted for by this model is $31 \%$, with suspensions the strongest predictor of being at-risk 
(standardised regression weight $\beta=.30$ ). Model fit indices are presented in Table 5 . These represent excellent model fit. A non-recursive model developed to test whether low achievement predicts suspensions was not statistically supported.

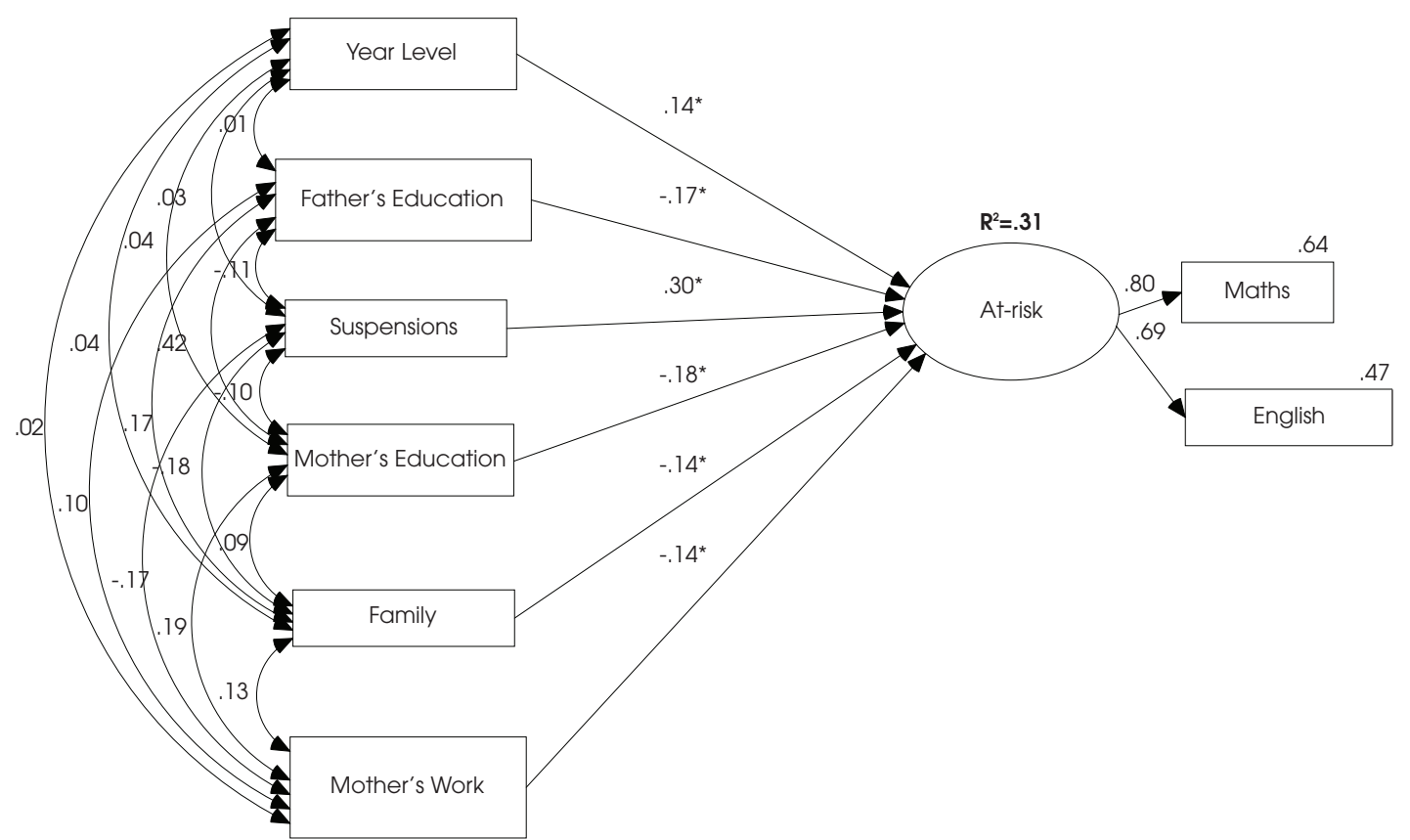

Figure 1: Model 1 Relationships between socioeconomic and structural variables and being at academic risk for non-Indigenous students ( $N=947)$, showing standardized regression weights and total variance (R2) for being at academic risk, ${ }^{*} \mathrm{p}<.001$.

Multi-group invariance was sought next to determine whether the model fit was equally good across both groups and if there were significant differences between the two groups of students. SEM makes this possible even when the sample sizes are considerably different (Byrne, 2004). According to the fit indices (Table 5) the best fitting model across the two groups was the structural weights model, which constrained the measurement weights (the estimation of English and maths grades) and the structural weights (the regression weights between exogenous variables, i.e., predictor variables, and the latent endogenous variable, "at-risk") to be equal across the two groups. Since the best fitting model across the two groups of students was the structural weights model, rather than the unconstrained model, the two groups differ significantly in the strength of relationship between predictor variables and outcome variable. This was also shown by the association tests of the preliminary analyses. Therefore, non-significant regression weights for the Indigenous group were trimmed from Model 1, resulting in Model 2, (Figure 2). All pathways retained were 
significant at $p<.001$, representing the best fitting model for the Indigenous data, and accounting for $45 \%$ of the observed variance in being "at-risk".

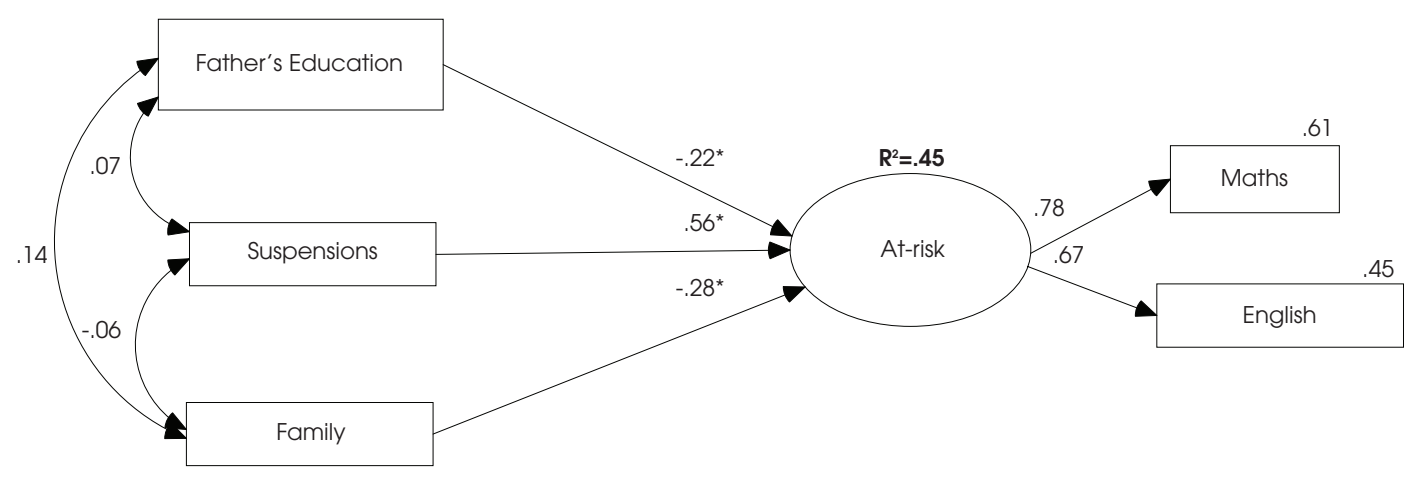

Figure 2: Model 2 Relationships between socioeconomic and structural variables and being at academic risk for Indigenous students $(\mathrm{N}=103)$, showing standardized regression weights and total variance (R2) for being at academic risk, ${ }^{*} \mathrm{p}<.001$.

\begin{tabular}{l|c|c|c|c|c|c|c|c}
\hline Model & $\chi^{2}$ & $d f$ & $p$ & $\chi^{2} / d f$ & GFI & CFI & RMSEA & N \\
\hline (a) 1 (Non-Indigenous) & 13.9 & 5 & .017 & 2.8 & .996 & .990 & .043 & 947 \\
\hline (b) Multi-group analyses & & & & & & & & \\
Unconstrained & 30.27 & 10 & .001 & 3.0 & .993 & .979 & .044 & 1050 \\
Measurement weights & 30.5 & 11 & .001 & 2.8 & .993 & .980 & .041 & 1050 \\
Structural weights & $\mathbf{3 5 . 1}$ & $\mathbf{1 7}$ & .006 & $\mathbf{2 . 1}$ & .992 & .982 & .032 & 1050 \\
Structural covariances & 91.6 & 38 & .000 & 2.4 & .980 & .946 & .037 & 1050 \\
Structural residuals & 92.1 & 39 & .000 & 2.4 & .980 & .946 & .036 & 1050 \\
Measurement residuals & 94.2 & 41 & .000 & 2.4 & .979 & .946 & .035 & 1050 \\
Independence model & 1038.9 & 56 & .000 & 18.6 & .766 & .000 & .129 & 1050 \\
\hline (c) 2 (Indigenous) & $\mathbf{2 . 0 8}$ & $\mathbf{2}$ & .352 & 1.04 & .992 & .999 & .021 & 103 \\
\hline
\end{tabular}

Table 5: Model Fit Indices

Examination of the models shows that suspensions are the strongest predictor of atrisk status, for non-Indigenous students (standardised Beta weight) $\beta=.30$, and Indigenous students, $\beta=.56$. Both are highly significant $(p<.001)$, with the Indigenous regression weight being twice as strong as that in the non-Indigenous group. Conversely, an intact family structure is a strong protective factor against at-risk status in both groups, $(\beta=-.28$, Indigenous group, $\beta=-.14$, non-Indigenous group). Lastly, paternal education also appears to act as a protective factor in both groups, even though this did not reach significance in the preliminary analyses for Indigenous students, illustrating the advantage of using SEM techniques. 


\section{Discussion}

This study examined predictors of low achievement, or being potentially at risk of dropping out of school in two North Queensland student groups, an Indigenous and a non-Indigenous group.

Inspection of the two models reveals that while socioeconomic predictors are significant, suspensions are the strongest predictors of being at risk of dropping out of school as measured by low achievement levels. This holds for both Indigenous and non-Indigenous students, with the model accounting for $45 \%$ of the observed variance in being at academic risk for Indigenous students and 31\% for non-Indigenous students. Thus suspensions, one index of behavioural adjustment to school, supersede the effects of socioeconomic adversity in both cultural contexts. There are, however, some differences between the two groups which might further interact with and have an impact upon adjustment.

The most notable difference is to be found in the degree by which family structure contributes to being at academic risk; in Indigenous students it is twice as strong as in non-Indigenous students, being highly significant in both groups. A higher proportion of Indigenous compared to non-Indigenous students live in blended or non-intact biological families (Table 4). This has complex historical antecedents in Australia and continuing widespread ramifications. However, it is clear that an intact family structure, whilst perhaps culturally determined, is a protective factor against being at academic risk, supporting previous research (e.g. Astone \& McLanahan, 1991). Schoon, Parsons, and Sacker (2004) concluded their longitudinal investigation of risk factors for educational failure by stating that socioeconomic adversity can be overcome by various social-psychological mechanisms, most markedly, parental educational aspirations for their child. When students are not living with their parents, this significant influence might be diminished or absent removing a protective factor from the student's immediate social context. Moreover, it is likely that parental aspirations are coupled with other support mechanisms such as increased monitoring that helps to augment students' engagement with their studies and perhaps their coping strategies.

Another important and significant difference between the two groups is that there is a high developmental trend for older non-Indigenous students to be at academic risk. This cannot be claimed for the Indigenous sample of students. While the percentage of Indigenous students at academic risk rose with each successive year, SEM modelling of this variable and chi-square association tests were not statistically significant, suggesting that for Indigenous students being at academic risk is as likely in Year 8 as in later years. This finding might signal a dissonance between Indigenous students and the cultural norms of their respective schools which is continuous and stable rather than peaking around Year 10 as with non-Indigenous students. 
A lower parental education level was significantly linked to being at academic risk in the non-Indigenous group when using path analyses and when the individual effects of these variables were tested by association tests, confirming prior research (Klebanov, Brooks-Gunn, \& Duncan, 1994). However, maternal educational level did not reach significance in the Indigenous group's SEM analysis, where all factors are simultaneously accounted and the covariance between factors is also estimated. It seems that only paternal education discriminated students at-risk from those not atrisk within this group of Indigenous students. A reason for this might be the higher covariance between paternal education and family structure compared to maternal education and family structure. In other words, there is a higher incidence of intact biological Indigenous families where the father is a graduate.

Limitations of the current study include the use of self-report questionnaires to assess outcome variables, the use of categorical rather than numeric achievement grades, and the cross sectional nature of the study. Lack of information obtained from participating schools with regard to students who might have learning disabilities but were included in the sample may also be a limiting factor. These students would need to be surveyed separately, possibly using alternative questionnaires.

Since a significant relationship was found between the predictor variables and the outcome variable even with the use of dichotomously coded variables, which lead to underestimates of Pearson's correlations, it can be concluded that the relationships found are not spurious but rather likely to have been underestimated. Similarly, the replication of findings from previous studies suggests that the use of self-report questionnaires was an acceptable and reliable way to access both predictor and outcome variables. Due to the cross-sectional nature of the study, confirmation that suspensions precede low achievement, even with the use of SEM techniques, is not possible. A longitudinally designed study is needed to establish causality among these variables and the degree of reciprocity that might be present between adolescent behaviour and achievement.

\section{Directions for future research and practitioner consideration}

In order to gain some insight into cultural mismatch between student and school the reasons for suspension need to be examined. This would give a better indication as to whether intervention to assist student behaviour should be applied at school, in the home environment or in relation to peers. Equally, the nature of the challenging behaviour needs to be carefully analysed using a contextual framework such as Bronfenbrenner's bioecological development theory (Bronfenbrenner, 1979). In Australia, Bitsika (2003) suggests that teachers are unsuccessful in assisting students with challenging behaviour because they are not treating each case according to its 
particular antecedents but rather applying general principles to behaviour modification. Sternberg and Grigorenko (2004) also advocate the use of context-based research to understand developmental trajectories, including risk and resilience pathways. Practitioners would therefore be able to assess student influences arising from the home, school or larger community. For example, it has been suggested that child-rearing practices in Indigenous cultures need to be taken into account in pedagogical practice. West (1994) proposed that Indigenous children are usually brought up with a degree of independence that involves learning to choose when to be involved in activities. They are not always controlled by others and will learn when they are not pushed or forced to learn. Indigenous children are often given social equality by adults, they are not expected to comply immediately with adult requests, and one Indigenous method of control is indirectness and circumspection. Thus some aspects of Indigenous cultures may be problematic for students in formal learning settings where the teacher is in control and where students are expected to comply immediately.

Similarly, values and conceptions of intelligence vary between cultures and this is likely to influence the relative emphasis that is placed on schooling and its outcomes by different cultural groups. Indigenous students' views of intelligence and the alignment of those views with traditional Western perspectives is not clear. Research conducted with rural Kenyans (Grigorenko et al., 2001), provides support for the notion that conceptions (and values) of intelligence vary across cultures. Rural Kenyans' conceptions of intelligence centre around four themes- knowledge and skills, respect, comprehension of how to handle real life problems and initiative. Among the Baoule of West Africa, service to the family and the community and politeness towards and respect for elders are seen as aspects of intelligence (Dasen, 1984). The Indigenous people of Australia are not homogeneous but rather derive from smaller clans speaking different languages. The cultural norms and traditions of these distinct groups have not been fully explored so it is difficult to understand the nature and level of cultural impact that Indigenous adolescents experience and the degree of dissonance between that and the dominant Western culture of their schools.

Resilience, conceptualized as academic success despite socioeconomic disadvantage and characterised by acceptable behavioural and motivational patterns, is likely to be the result of processes involving home and school, as well as community factors and belief systems. These may be brought to light through in-depth consultations with resilient students and students at-risk in order for contextual comparisons to be made. We need to learn how challenging behaviour is linked to particular coping mechanisms, attitudes and beliefs and conversely, how resilient students cope and what their belief systems centre around. 
Empirical work suggests that parenting is highly instrumental in promoting adjustment or behaviour problems. Low family socioeconomic status (SES) which has been associated with a variety of child outcomes, for example, greater externalizing behavioural problems, has also been characterized by different styles of parental interaction with their children than in high SES (Chen \& Berdan, 2006). Bronfenbrenner's (1979) theory of human development stresses the importance of the quality of the relationships of adolescents with their primary care givers. Bronfenbrenner emphasised that an enduring emotional relationship promotes motivation, attentiveness, sensitivity and perseverance on the part of both parent and child, contributing to sustained, active orientation to the environment. By contrast, the absence of such a relationship hinders psychological development and, in the face of additional stresses such as poverty, can predispose problem behaviours. In regard to dropping out of school and long term career planning, parents are important influences on their children's plans (e.g. Weishaar, Green, \& Craighead, 1981) however, in some cases there is little assistance available to guide them (Osguthorpe, 1976). Would counsellors or peers be as effective as parents in guiding an adolescent through the many issues that arise during the years of secondary schooling? Although counsellors have the advantages of training and experience, parents have the advantages of greater knowledge of their children and stronger bonds with them. Unlike counsellors with full schedules, parents have time to devote to an intensive and systematic career plan suited to the needs of their adolescent. Even though counsellors might offer broadly focused group programs involving orientation, testing, and so on, parents offer the opportunity for personal attention to help their children sort out ideas, information, values, and so on. Competent care giving is foremost in promoting resilience (Wyman et al., 1999).

Where parenting or care-giving is inadequate for optimal school socialisation and coping, support needs to be given to students and parents. If this is not possible, for example in the cases where students are in state care, support needs to be sought perhaps with a mentoring teacher if resilience is to develop. Qualitative studies (e.g. Howard \& Johnson, 2000a; 2000b) have suggested that support emanating from school or community sources is instrumental in promoting resilience. However, in Queensland for example, school guidance officers, the most proximal source of assistance for a troubled adolescent outside the home, have the dual role of career advice and academic welfare. Guidance officers are allocated to schools on the basis of enrolment numbers in Queensland, with one officer per 1100 students enrolled. It is clear that students from disadvantaged backgrounds at academic risk, whether because of internalising or externalising problems, have critical emotional needs as well as career planning needs which guidance officers have scant time to provide. In particular, when a guidance officer has to play a role in family abuse cases the disparity between the demands of the case and the time available to the guidance officer might become insurmountable. 
Thompson (2002) urges for more resources for schools but advocates caution for both practitioners and researchers. Pragmatism in providing students with the support to achieve their goals may involve a balance between idealism and realism. Recognising the difficulties in achieving more equitable long term changes can be depressing. When educators have 'realistic' expectations of what they can achieve it can sometimes mean lowered expectations, which translate into low achievement for students. On the other hand, educators' emancipatory ideas can become demoralizing self-realisations of futility, or alternative forms of authoritarianism. The tension between realism and idealism needs to be recognised if it is to be productive (Thompson, 2002). At the same time, collaboration between practitioners, educators and guidance officers, and researchers needs to be developed when focusing on students' behaviour, recognising the constraints of political climate and the perspectives of those involved. Harris and Thomson (2006) urge researchers from different strands, disciplines and theoretical traditions to read each others' work and research and write together.

\section{Acknowledgements}

Academic Achievement, Students at-risk This research is proudly supported by the Queensland Government's Growing the Smart State program and may be used to assist public policy development. The State of Queensland accepts no responsibility for decisions or actions resulting from any information supplied. The views and information contained in the research do not necessarily represent the views or opinions of the Queensland Government and carry no endorsement by the Queensland Government.

\section{References}

Arbuckle, J. L., \& Wothke, W. (1999). Amos 4.0 Users' Guide. Chicago: SmallWaters.

Astone, N. M., \& McLanahan, S. S. (1991). Family structure, parental practices and high school completion. American Sociological Review, 56, 309-320.

Australian Bureau of Statistics (ABS). (2004). Education and Training Primary and Secondary Education. Retrieved September 11, 2005, from the Australian Bureau of Statistics Web site: http://www.abs.gov.au/ausstats/abs@.nsf/Lookup/NT0001794A

Baron, R. M., \& Kenny, D. A. (1986). The moderator - mediator variable distinction in social psychological research: conceptual, strategic, and statistical considerations. Journal of Personality and Social Psychology, 51(6), 1173-1182.

Batten, M., \& Russell, J. (1995). Students at-risk: A Review of Australian Literature, 1980-1994. Australia; Victoria: Australian Council for Educational Research. 
Battin-Pearson, S., Newcomb, M. D., Abbott, R. D., Hill, K. G., Catalano, R. F. \& Hawkins, J. D. (2000). Predictors of early high school dropout: A test of five theories. Journal of Educational Psychology, 92(3), 568-582.

Bitsika, V. (2003). "But I'm Not Really Bad": Using an idiographic versus a nomothetic approach to understand the reasons for difficult behaviour in children. Australian Journal of Guidance and Counselling, 13(1), 54-68.

Bentler, P. M. (1990). Comparative fit indexes in structural models. Psychological Bulletin, 107, 238-246.

Bollen, K. A. (1989). Structural Equations with Latent Variables. New York: Wiley.

Bradley, G. (1992). Increasing student retention. Youth Studies Australia, 11(2), 37-42.

Bronfenbrenner, U. (1979). The Ecology of Human Development - Experiments by Nature and Design. Cambridge: Harvard University Press.

Bronfenbrenner, U. (1986). Alienation and the four worlds of childhood. Phi Delta Kappan, 67, 430-436.

Byrne, B. (2001). Structural Equation Modelling with AMOS. Mahwah, NJ: Lawrence Erlbaum Associates.

Byrne, B. (2004).Testing for multi-group invariance using AMOS graphics: a road less travelled. Structural Equation Modelling, 11(2), 272-300.

Candy, L., \& Baker, M. (1992). What Berengarra school has learnt about working with families. In J. Elkins \& J. Izard (Eds.), Student Behaviour Problems: Contexts, Initiatives, and Programs (pp. 276-282). Hawthorn: ACER.

Chamberlain, C., \& MacKenzie, D.(1996). School students at-risk. Youth Studies Australia, 15,(4), 11-18.

Chen, E., \& Berdan, L. E. (2006). Socioeconomic status and patterns of parental adolescent interactions. Journal of Research on Adolescence, 16(1), 19-27.

Christenson, S. L., Hurley, C. M., Sheridan ,S. M., \& Fenstermachor, K. (1997). Parents' and school psychologists' perspectives on parent involvement activities. School Psychology Review, 26, 111-130.

Dasen, P. (1984). The cross-cultural study of intelligence: Piaget and the Baoule. International Journal of Psychology, 19, 407-434.

Desforges, C., \& Abouchaar, A. (2003). The Impact of Parental Involvement, Parental Support and Family Education on Pupil Achievements and Adjustment: A Literature Review (Research report 433). UK: DFES.

Friedman, R. J., \& Chase-Landsdale, P. L. (2002). Chronic adversities. In: M. Rutter and E. Taylor (Eds.) Child and adolescent psychiatry (4th ed.) (pp. 261-276). London: Blackwell.

Garmezy, N., \& Rutter, M. (Eds.). (1983). Stress, Coping and Development in Children. New York: McGraw-Hill.

Gordon-Rouse, K. A. (2001). Resilient students' goals and motivation. Journal of Adolescence, 24, 461-472. 
Gresham, F. M., Lane, K. L., MacMillan, D. L., \& Bocian, K. M. (1999). Social and academic profiles of externalizing and internalizing groups: Risk factors for emotional and behavioral disorders. Behavioral Disorders, 24(3), 231-245.

Grigorenko, E. L., Geissler, P. W., Prince, R., Okatcha, F., Nokes, C., Kenny, D. A., et al. (2001). The organisation of Lao conceptions of intelligence: A study of implicit theories in a Kenyan village. International Journal of Behaviour Development, 25, 367-378.

Harris, A., \& Thomson, P. (2006, January). Leading Schools in Poor Communities. What Do We Know and How Do We Know It? Paper presented at the International Congress of School Effectiveness and Improvement, Fort Lauderdale.

Hill, A., Dawes, G., Boon, H., \& Hillman, W. (2005). Investigating the Factors That Lead to Disengagement in Students of The Upper Ross. Townsville: James Cook University.

Hinshaw, S. P. (1992). Externalizing behavior problems and academic underachievement in childhood and adolescence: Causal relationships and underlying mechanisms. Psychological Bulletin, 111, 127-155.

Howard, S., \& Johnson, B. (2000a). Tracking student resilience. Children Australia. 24(3), $14-23$.

Howard, S., \& Johnson, B. (2000b). Young Adolescents Displaying Resilient and NonResilient Behaviour. Insights from a Qualitative Study - Can Schools Make A Difference? Retrieved August 8, 2003, from http://www.aare.edu.au/00pap/how00387 .htm

Jimerson, S., Egeland, B., Sroufe, L. A., \& Carlson, B. (2000). A prospective longitudinal study of high school dropouts examining multiple predictors across development. Journal of School Psychology, 38(6) 525-549.

Joreskog, K. G., \& Sorbom, D. (1984). LISREL VI: analysis of linear structural relationships by the method of maximum likelihood (3rd ed.). Mooresvile, IN: Scientific software.

Joreskog, K. G., \& Sorbom, D. (1989). LISREL 7: A Guide to the Program and Applications. Chicago, IL: SPSS Publications.

Kelley, S. A., Brownell, C. A., \& Campbell, S. B. (2000). Mastery motivation and selfevaluative affect in toddlers: Longitudinal relations with maternal behavior. Child Development, 71, 1061-1071.

Klebavov, P. K., Brooks-Gunn, J., \& Duncan, G. J. (1994). Does neighborhood and family poverty affect mothers' parenting, mental health and social support? Journal of Marriage and the Family, 56, 441-455.

Kline, R. B. (1998). Principles and Practice of Structural Equation Modelling. New York: Guilford.

Lamborn, S. D., Mounts, N. S., Steinberg, L., \& Dornbusch, S. M. (1991). Patterns of competence and adjustment among adolescents from authoritative, authoritarian, indulgent and neglectful families. Child Development, 62, 1049-1065.

Lane, K. L. (1999).Young students at-risk for antisocial behaviour: The Utility of Academic and Social Skills Interventions. Journal of Emotional and Behavioural Disorders, 7(4), 211-223. 
Males, M. A. (1996). The Scapegoat Generation: America's War on Adolescents. Monroe, ME: Common Courage Press.

MacCallum, R. C., \& Austin, J. T. (2000). Applications of structural equation modelling in psychological research. Annual Revue of Psychology, 51, 201-226.

Maruyama, G. M. (1998). Basics of Structural Equation Modelling. Thousand Oaks, CA: Sage.

McEvoy, A., \& Welker, R. (2000). Antisocial behaviour, academic failure, and school climate: A critical review. Journal of Emotional and Behavioural Disorders, 8(3), 130-140.

Mellor, S. \& Corrigan, M. (2004). The Case for Change: A Review of Contemporary Research on Indigenous Education Outcomes. Victoria: ACER.

Miller, M., \& Spooner, C. (Eds.) (2004). A Head Start for Australia: An Early Years Framework - A Summary. Retrieved January 7, 2006 from Commission for Children and Young People and Child Guardian (QLD) Web site: http://www.childcomm. qld.gov.au/about/publications/headStart04.html

McMillan, J. M., \& Marks, G. N. (2003). School Leavers in Australia: Profiles and Pathways. (LSAY Research Report NO 31). Victoria: ACER.

Muthen, B. O. (1984). A general structural equation model with dichotomous, ordered categorical and continuous latent indicators. Psychometrika, 49, 115-132.

Odgers, R. (2003, Nov 17th). Students expelled at the rate of 30 a week. The Courier Mail, pp. 1-2.

OECD (2001). Knowledge and Skills for Life: First Results From PISA. Paris: Author.

Osguthorpe, R. (1976). The Career Conversation: Training Parents to Help Their Children Make Career Decisions. North Greece, NY: Greece Central School District. (ERIC Document Reproduction Service No. ED 159 534)

Paulson, S. E., Marchant, G. J., \& Rothlisberg, B. A. (1998). Early adolescents' perceptions of patterns of parenting, teaching and school atmosphere: implications for achievement. Journal of Early Adolescence, 18(1), 5-26.

Reynolds, C. R., Lowe, P. A., \& Saenz, P. (1999). The problem of bias in psychological assessment. In T. B. Gutkin \& C. R. Reynolds (Eds.), Handbook of School Psychology (3rd ed.) (pp. 549-595). New York: Wiley.

Richters, J. E., \& Martinez, P. E. (1993). Violent communities, family choices, and children's chances: An algorithm for improving the odds. Development and Psychopathology, 5, 609-627.

Rothman, S. (2004). Staying longer at school and absenteeism: Evidence from Australian research and the longitudinal surveys of Australian youth. International Education Journal, 5(1), 113-123.

Rutter, M. (2002). Nature, nurture, and development: From evangelism through science toward policy and practice. Child Development, 73(1), 1-21.

Rutter, M., Giller, H. \& Hagell, A. (1998). Anti-Social Behaviour by Young People. Cambridge, UK: Cambridge University Press. 
Schoon, I. (2006). Risk and Resilience: Adaptation in Changing Times. London: Cambridge University Press.

Schoon, I., Parsons, S., \& Sacker, A. (2004). Socioeconomic adversity, educational resilience, and subsequent levels of adult adaptation. Journal of Adolescent Research, 19(4), 383-404.

Solomon, Y., \& Rogers, C. (2001). Motivational patterns in disaffected school students: Insights from pupil referral unit clients. British Educational Research Journal, 27(3), 331-345.

Sternberg R.J., \& Grigorenko, E. L. (2004). Why we need to explore development in its cultural context. Merrill-Palmer Quarterly, 50(3), 369-386.

Sternberg, R. J., Grigorenko, E. L., \& Bundy, D. A. (2001). The predictive value of IQ. Merrill-Palmer Quarterly, 47(1), 1-41.

Teese, R. (2001). Academic Success and Social Power: Examinations and Inequality. Melbourne, Vic: Melbourne University Press.

Thomson, P. (2002). Schooling the Rustbelt Kids: Making the Difference in Changing Times. Sydney: Allen \& Unwin.

Werner, E. (1990). Protective factors and individual resilience. In S. J. Meisels \& J. P. Shonkoff (Eds.), Handbook of Early Childhood Intervention (pp. 97-116). Cambridge, U.K.: Cambridge University Press.

Werner, E. E. (1993). Risks, resilience, and recovery: perspectives from the Kauai Longitudinal Study. Development and Psychopathology, 5, 503-515.

West, L. (1994). Cultural behaviour, conflict and resolution. In S. Harris \& M. Malin (Eds.), Aboriginal Kids in Urban Classrooms (7-19). Wentworth Falls, NSW: Social Science Press.

Weishaar, M., Green, B., \& Craighead, L. (1981). Primary influencers of initial vocational choices for college women. Journal of Vocational Behaviour, 18, 67-78.

Willis, P. (1979).Cultural production is different from cultural reproduction is different from social reproduction is different from reproduction. Interchange, 12(2-3), 48-67.

Withers, G., \& Batten, M.(1995). Programs for At-Risk Youth, A Review of American, Canadian and Australian Literature Since 1984. Melbourne: ACER.

Wyman, P. A., Cowen, E. L., Work, W. C., Hoyt-Mayers, L., Magnus, K. B., \& Fagen, D.B. (1999). Caregiving and developmental factors differentiating young at-risk urban children showing resilient versus stress affected outcomes: a replication and extension. Child Development, 70, 645-659.

Yen, C-J, Konold, T. R., \& McDermott, P. A. (2004). Does learning behaviour augment cognitive ability as an indicator of academic achievement? Journal of School Psychology, 42, 157-169. 